\title{
Comparative Histological Study on the Spleen of Human (Homo sapiens), Cow (Bos indicus) and Goat (Capra hircus)
}

\author{
Alim $A,{ }^{1}$ Nurunnabi ASM,,$^{2 *}$ Ara $S,{ }^{2}$ Mahbub $S,{ }^{3}$ Mohanta LC $C^{4}$ \\ ${ }^{1}$ Department of Anatomy, Khulna Medical College, Khulna, Bangladesh, ${ }^{2}$ Department of Anatomy, Dhaka Medical College, \\ Dhaka, Bangladesh, ${ }^{3}$ Department of Anatomy, Shahabuddin Medical College, Dhaka, Bangladesh, ${ }^{4}$ Department of Biological \\ Sciences, Bangladesh Council for Scientific and Industrial Research (BCSIR), Dhaka, Bangladesh
}

\section{*Corresponding Author: \\ Dr. Abu Sadat Mohammad Nurunnabi \\ Lecturer, Department of Anatomy, \\ Dhaka Medical College, Dhaka-1000. \\ Email: shekhor19@yahoo.com}

\section{Citation}

Alim A, Nurunnabi ASM, Ara S, Mahbub S, Mohanta LC. Comparative histological study on the spleen of human (Homo sapiens), cow (Bos indicus) and goat (Capra hircus). Nepal Journal of Medical sciences 2012;1(2):64-7.

\begin{abstract}
Background: The spleen is the largest single mass of lymphoid tissue in all vertebrates. It is presumed that the architectural design of spleen of domestic and wild animal is different from man. Exact knowledge of histological structure of human, cow and goat can be helpful to differentiate among different species in vertebrates.
\end{abstract}

Methods: A descriptive type of study was carried out in the department of Anatomy, Dhaka Medical College, Dhaka, from January to December 2008. Thirty human spleens were collected from the unclaimed dead bodies that were under examination in the Department of Forensic Medicine of Dhaka Medical College, Dhaka. Spleens from cow and goat were collected from a slaughter house of Dhaka city. A total of 15 relatively fresh human samples, six from cows and six from goats were selected for histological study.

Results: The mean thickness of the splenic capsule was $111.56 \pm 21.45 \mu \mathrm{m}$ in human, $196.88 \pm 11.91 \mu \mathrm{m}$ in cow and $251.44 \pm 12.56 \mu \mathrm{m}$ in goat. The difference in thickness of the splenic capsule was statistically significant among the human, cow and goat ( $\mathrm{p}<0.001)$. However, no difference was found in diameter, number and percentage of the white pulp of the spleen among those species.

Conclusion: There was statistically significant difference in the thickness of splenic capsule but no difference was found in the diameter, number and percentage of white pulp in the spleen of these species.

Keywords: Comparative anatomy; histology; spleen; capsule; white pulp

\section{Background:}

$\mathrm{C}$ Anatomy is the scientific study of the similarities and differences in the structure of different species. Comparative anatomy helps to show how organisms function, how they develop, and how they are linked by evolution, the process by which organisms change over many generations. ${ }^{1}$ The spleen is the largest single mass of lymphoid tissue. It is almost entirely covered by peritoneum, which is adherent to its capsule. It is present in all the vertebrates. ${ }^{2}$

Spleen is classified into defensive type, storage type and intermediate type. Defensive type occurs in man, rabbit and mare. Storage type occurs in horse, dog and cat. Intermediate type occurs in ruminants and swine. ${ }^{3}$ The organ is demanding constant attention from anatomical, immunological and clinical points of view.

The spleen is an important site for haemopoiesis in early life 
and break down of old red blood cells (RBC) in adult life in all vertebrates. ${ }^{4}$ It gives immune protection. It recycles iron by splenic macrophage of red pulp. Spleen is a flaccid bag that serves as a storage site of blood. It presumed that the architectural design of spleen of domestic and wild animal is different from man. ${ }^{5}$ Animals depending on natural heal up of the mechanical injury must depend on spleen for its blood transfusion, which demands the contractility of the spleen itself. Therefore, the connective tissues and smooth muscles in the capsule and trabeculae are prominent in ruminants. ${ }^{5,6}$

Exact knowledge of histological structure of the spleen of human (Homo sapiens), cow (Bos indicus) and goat (Capra hircus) can be helpful to differentiate among different species in vertebrates. The aim of the present study is to compare the histological structure of the spleen of human, cow and goat.

\section{Methods:}

\section{Collection of Sample}

A cross-sectional descriptive study was carried out in the Department of Anatomy, Dhaka Medical College, Dhaka, from January to December 2008 based on the postmortem collection of spleens of man, cow and goat. The samples of human spleen were collected from the unclaimed dead bodies that were under examination in the Department of Forensic Medicine of Dhaka Medical College, Dhaka, from February to October 2008. After legal formalities the samples were collected within 24-36 hours of death without any sign of putrefaction.

All the human samples were collected from medicolegal cases. During collection appropriate age, sex and cause of death were noted from morgue's record book. Spleens from cow and goat were collected from a slaughter house of Dhaka city within 5 hours of slaughtering.

The samples were brought to the Department of Anatomy, Dhaka Medical College, Dhaka. The samples were tagged immediately, which was bearing a code number for subsequent identification. Soon after collection each sample was gently washed in tap water on a dissection tray. Blood and blood clots were removed as far as possible. Then the samples were fixed in $10 \%$ formol saline solution.

\section{Dissection of the spleen}

The $10 \%$ formol saline fixed samples were washed with the free flowing tap water to wash away the formol saline so as to avoid irritation of eyes and nasal mucosa by the formalin vapour and also for somewhat softening of the fixed tissue. Then samples were taken in a metallic tray and the surrounding fats and other unwanted tissues were removed carefully with the help of sharp scissors, fine dissecting forceps and BP blade to expose spleen and its related structure.

\section{Preparation of histological slides}

The spleens were fixed in $10 \%$ formol saline in a plastic container. A total of 15 human samples, six from cows and six from goats were selected for histological study. The spleen was placed on a metallic tray in such a way that the upper border lies at the top and the inferior border at the base. A sharp knife was placed on the hilum of the spleen, and it was cut sharply obtain a slice of tissue having $3 \mathrm{~mm}$ in thickness. Each of the samples was fixed with $10 \%$ formol saline for 24 hours. Then the splenic capsule was dissected from both superior and inferior surfaces of the spleen.

The tissues were washed in running tap water, dehydration was done with ascending grades of alcohol, cleared with xylene, infiltrated and embedded in paraffin. Paraffin blocks were cut at $5 \mathrm{~mm}$ thickness and were stained with routine Harris' Haematoxylin and Eosin (H \& E) stain. One good prepared slide from each of the tissue blocks was chosen for the study.

\section{Microscopic measurement}

The light compound microscope which was used for the microscopic measurement was Olympus CHB, made in Tokyo, Japan. All the variables were studied under low power objective (x 10 objective, $x 10$ eyepiece).

\section{Measurement of the thickness of the splenic capsule}

The thickness of the splenic capsule was determined with the help of an ocular and a stage micrometer. The thickness of the splenic capsule of each species was measured from the outer margin of the capsule to the inner margin at three different points and the average value was taken. The stage micrometer calibration was focused under the objective to be used and the ocular micrometer calibration was superimposed in such a way that starting mark on the ocular micrometer matches exactly with a starting mark on the stage micrometer.

Then the markers on the stage and the ocular micrometers corresponding to each other most closely were noted. In this way how many smallest division of the ocular micrometer corresponds to how many smallest division of the stage micrometer was determined. Measurement was done by how many ocular micrometer divisions correspond to the thickness of the splenic capsule. Then the average thickness was calculated in $\mathrm{mm}$ by conversion measurement of an ocular micrometer and a stage micrometer. ${ }^{7}$

\section{Measurement of the diameter of white pulp of the spleen}

The white pulp of the spleen was spherical rather than 
rounded, which was somewhat difficult in measuring the actual diameter. To overcome such type of drawback, the numbers of ocular micrometer divisions were read out from near to remote margins of the white pulp and measurements were taken twice for each pulp i.e. one was maximum transverse diameter and another perpendicular to the first one.

Then the numbers of micrometer divisions were multiplied by the correlation factor derived earlier keeping the magnification constant ( $x 10$ objective, $x 10$ eyepiece). Therefore, the diameter of white pulps was calculated as follows:

Diameter of white pulp $=$ (Maximum transverse diameter + Maximum perpendicular diameter $) \div 2$

Then the average diameter was calculated in $\mathrm{mm}$ by conversion measurement of an ocular micrometer and a stage micrometer ${ }^{7}$

\section{Estimation of the number of white pulp of the spleen per sq. $\mathrm{mm}$ area of the microscopic field}

According to Rayhan et al. ${ }^{7}$ the stained tissue section on the slide was divided into three equal parts by a computer generated, photographically produced equal sized room over a transparent plastic sheet by drawing three lines which radiated from the centre towards the periphery at 10 o'clock, 2 o'clock and 6 o'clock position. Then, this sheet was fixed on the top of the cover slip by adhesive tape. The centre of this sheet corresponded with the centre of the tissue section. From each triangular area, one microscopic field was selected near the centre for study. Thus from each slide, three different fields were chosen for counting the number of white pulp of spleen. Therefore, from human spleen, a total of 45 fields and from both the cow and the goat 18 fields were taken for the study.

A counting circle of $5 \mathrm{~mm}$ diameter was printed on a transparent plastic sheet, which was cut to fit into the eyepiece of the light microscope. Thus a black circular outline was superimposed over the actual microscopic field. The circle encircled some total of the white pulp, while some other white pulps were partly included inside that circle. However, the rest of the white pulps were also seen. Considering this circle as the field to be studied (rather than the whole microscopic field), the portions of the white pulps inside this field were taken in consideration by an eye estimate e.g. $1,0.75,0.5,0.25$ etc.

From the three counts of three different fields of each slide, an average count was calculated for each slide. Thus, the average counts of the slides for each species were available. The count was then converted into number per square mm by conversion measurement of an ocular micrometer and a stage micrometer. ${ }^{6-8}$

\section{Amount of white pulp of the spleen in percentage}

To measure the area of white pulp, the well-resoluted area of the slide was chosen and several photomicrographs were taken by using a Sony cyber-shot (DSC-W130) digital camera, made in Japan. Then those were scanned by using cannon scanner, made in Japan and taken into a computer.

The scanned photomicrographs were transferred to the AutoCAD software. At first, the measurement of full photomicrograph was taken, and then the area occupied by the white pulp was measured and expressed in percentage.

\section{Statistical processing of data}

The data collected from the histological studies were processed and statistical analyses were done by one-way Anova test, using the SPSS 11.0 version.

\section{Ethical clearance}

This research work was approved by the Ethical Review Committee of Dhaka Medical College, Dhaka.

\section{Results:}

The difference in thickness of the splenic capsule was statistically significant among the human (Homo sapiens), cow (Bos indicus) and goat (Capra hircus) $(\mathrm{p}<0.001)$. The thickness of the capsules of the spleens of different species are shown in table 1.

\section{Table 1: Thickness of splenic capsule in different species}

\begin{tabular}{cc}
\hline Species & $\begin{array}{c}\text { Thickness of the capsule } \\
\text { in } \mu \mathrm{m}(\mathrm{Mean} \pm \mathrm{SD})\end{array}$ \\
\hline $\begin{array}{c}\text { Human } \\
(\mathrm{n}=15)\end{array}$ & $\begin{array}{c}111.56 \pm 21.45 \\
(74.97-139.26)\end{array}$ \\
Cow \\
$(\mathrm{n}=6)$ & $196.88 \pm 11.91$ \\
Goat & $(179.92-208.84)$ \\
$(\mathrm{n}=6)$ & $251.44 \pm 12.56$ \\
& $(230.26-267.75)$ \\
\hline Human vs Cow & $\mathrm{P}$ value \\
Human vs Goat & $<0.001$ \\
Cow vs Goat & $<0.001$ \\
\end{tabular}

Figures in parentheses indicate range. Comparison among species done by One-way Anova (PostHoc)

However, no difference was found in diameter, number and percentage of the white pulp of the spleen among those species. The diameter, number and percentage of the white 
pulps of the spleens of different species are shown in table 2 .

Table 2: Diameter, number and amount of white pulp in different species

\begin{tabular}{cccc}
\hline Species & $\begin{array}{c}\text { Diameter } \\
\text { of white } \\
\text { pulp in mm } \\
(\text { Mean } \pm \text { SD) }\end{array}$ & $\begin{array}{c}\text { Number of } \\
\text { white pulp } \\
\text { per sq. mm } \\
(\text { Mean } \pm \text { SD) }\end{array}$ & $\begin{array}{c}\text { Amount of } \\
\text { white pulp in } \\
\text { percentage } \\
\text { (Mean } \pm \text { SD) }\end{array}$ \\
\hline $\begin{array}{c}\text { Human } \\
(\mathrm{n}=15)\end{array}$ & $\begin{array}{c}0.32 \pm 0.01 \\
(0.30-0.34)\end{array}$ & $\begin{array}{c}2.23 \pm 0.86 \\
(0.25-0.38)\end{array}$ & $\begin{array}{c}23.36 \pm 1.59 \\
(20.76-27.21)\end{array}$ \\
$\begin{array}{c}\text { Cow } \\
(\mathrm{n}=6)\end{array}$ & $\begin{array}{c}0.35 \pm 0.05 \\
(0.28-0.42)\end{array}$ & $\begin{array}{c}1.98 \pm 0.69 \\
(1.70-3.40)\end{array}$ & $\begin{array}{c}22.22 \pm 1.42 \\
(20.76-24.45)\end{array}$ \\
$\begin{array}{c}\text { Goat } \\
(\mathrm{n}=6)\end{array}$ & $\begin{array}{c}0.35 \pm 0.03 \\
(0.30-0.38)\end{array}$ & $\begin{array}{c}1.98 \pm 0.69 \\
(1.70-3.40)\end{array}$ & $\begin{array}{c}22.17 \pm 0.85 \\
(21.05-23.15)\end{array}$ \\
\hline & $\mathrm{P}$ value & $\mathrm{P} \mathrm{value}$ & $\mathrm{P}$ value \\
\hline $\begin{array}{c}\text { Human } \\
\text { vs Cow }\end{array}$ & $>0.05$ & $>0.50$ & $>0.10$ \\
$\begin{array}{c}\text { Human } \\
\text { vs Goat }\end{array}$ & $>0.05$ & $>0.50$ & $>0.05$ \\
Cow vs & $>0.50$ & $>0.50$ & $>0.50$ \\
Goat & & & \\
\hline
\end{tabular}

Figures in parentheses indicate range. Comparison among species done by One-way Anova (PostHoc)

\section{Discussion:}

According to the present study, the mean thickness of the splenic capsule was found $111.56 \pm 21.45 \mu \mathrm{m}$ in human, $196.88 \pm 11.91 \mu \mathrm{m}$ in cow and $251.44 \pm 12.56 \mu \mathrm{m}$ in goat. The difference in thickness of the splenic capsule was statistically significant among different species $(p<0.001)$. According to Zidan et al. the camel spleen is composed of a thick capsule surrounding the splenic parenchyma. ${ }^{9}$ The capsule is $292 \pm 106 \mu \mathrm{m}$ thick and divided into clearly demarcated outer and inner layers. The outer layer $(113 \pm 39$ $\mu \mathrm{m})$ consists mainly of connective tissue including collagen, elastic and reticular fibres with few smooth muscle cells. The inner layer $(180 \pm 81 \mu \mathrm{m})$ is composed predominantly of smooth muscle cells supported by reticular, collagen and elastic fibres.

He also stated that the splenic capsule of the carnivous animals were found thicker than that of humans. The findings of the present study was similar to Rayhan et al. ${ }^{7}$ and Rodrigues et al. ${ }^{10}$ and lower than that of described by Crossman. ${ }^{2}$

However to the best of our knowledge, this was the first study ever on spleen of different vertebrates in Bangladesh. Therefore, further studies with larger sample and high technical back up are recommended.

\section{Conclusion:}

There was statistically significant difference in the thickness of spleenic capsule but no difference was found in the diameter, number and percentage of white pulp in the spleen of these species.

\section{Acknowledgement:}

We would like to acknowledge the authority of the Health, Nutrition \& Population Sector Programme (HNPSP) of Directorate General Health Services (DGHS) of the Government of the People's Republic of Bangladesh for providing us with the grant for research.

\section{Conflict of interest : none disclosed}

\section{References:}

1. Kardong K. Vertebrates: comparative anatomy, function, evolution. $6^{\text {th }}$ ed. New York: McGraw-Hill; 2011.

2. Crossman AR. Abdomen. In: Standring S, Ellis H, Heally JC, et al. eds. Gray's Anatomy: The anatomical basis of clinical practice. $39^{\text {th }}$ ed. Edinburgh: Elsevier Churchill Livingstone; 2005.

3. Fishbeck DW, Sibastiani A. Comparative anatomy: manual of vertebrate dissection. $2^{\text {nd }} \mathrm{ed}$. London: Morton Publishing Company; 2008.

4. Mebius RE, Kraal G. Structure and function of the human spleen. Nat Rev Immunol 2005;5: 606-72.

5. Radostits OM, Gay CC, Blood DC, et al. eds. Diseases of the spleen, lymphadenopathy and thymic disease. In: Veterinary medicine: a textbook of the diseases of cattle, sheep, pigs, goats and horses. $9^{\text {th }}$ ed. London: W. B. Saunders; 2000.

6. Press CM, Landsverk T. Immune system. In: Eurell JAC, Eurell JA, Frappier BL, et al. eds. Dellmann's textbook of veterinary histology. $6^{\text {th }}$ ed. New York: Blackwell; 2006.

7. Rayhan KA, Ara S, Kishwara S, et al. Histological study of human spleen. Bangladesh J Anat 2008;6:71-6.

8. Sisson S. The anatomy of domestic animals. $2^{\text {nd }}$ ed. Philadelphia: W. B. Saunders; 1927.

9. Zidan M, Kassem A, Dougbag A, et al. The spleen of the one humped camel (Camelus dromedarius) has a unique histological structure. J Anat 2000;196:425-32.

10. Rodrigues CJ, Sacchetti JCI, Rodrigues AJ, Jr. Age related change in the elastic fiber network of the human splenic capsule. Lymphology 1999;32:64-9. 